\title{
INTEGRATED TWIN TOWERS DAN ISLAMISASI ILMU
}

\author{
H. Syaifuddin \\ (Dosen IAIN Sunan Ampel Surabaya)
}

\begin{abstract}
Abstrak
Tulisan ini menunjukkan beberapa pemikiran sebagai berikut: Pertama, desain integrated twin towers dilakukan dalam rangka menyongsong perubahan IAIN menjadi UIN Sunan Ampel. Dalam desain integrated twin towers posisi keilmuan agama dan umum tidak dicampur menjadi satu, tetapi dibiarkan berjalan sendiri-sendiri, dan pada saat tertentu dipertemukan untuk saling berdialog. Dalam desain integrated twin towers keilmuan agama tidak bermaksud mengintervensi keilmuan umum, karena keilmuan umum dianggap sudah mapan, jadi biarkan berjalan secara wajar pada posisinya; yang penting di antara kedua keilmuan itu bisa saling berkomunikasi.

Kedua, desain Islamisasi ilmu dilakukan dalam rangka mengkritisi keilmuan umum yang notabene banyak bersumber dari Barat dan bersifat sekuleristik, materialistik, dan individualistik. Dalam proses Islamisasi ilmu, keilmuan Islam berupaya mengintervensi keilmuan umum dalam rangka memfilterisasinya sehingga keilmuan tersebut menjadi Islami. Jadi Islamisasi ilmu berarti memberikan wawasan (world view) keislaman kedalam keilmuan umum.

Ketiga, meskipun ada perbedaan di antara desain integrasi keimuan berbasis Islamisasi ilmu dengan integrated twin towers, namun juga ada persamaannya. Perbedaannya terletak pada proses (epistemologi)-nya. Dalam prosesnya, desain Islamisasi ilmu berusaha mengintervensi kajian keilmuan umum dengan pendekatan kajian keagamaan; sedangkan dalam desain integrated twin towers keilmuan agama tidak bermaksud mengintervensi kajian keilmuan umum. Persamaannya terletak pada kurikulum (ontologi) dan tujuan (aksiologi). Dalam hal kurikulum, keilmuan yang dikaji adalah bidang kajian keilmuan agama dan umum. Sementara dalam hal tujuan, Islamisasi ilmu dan integrated twin towers sama-sama bertujuan untuk mengintegrasikan keilmuan agama dan umum, mendialogkan, mengkomunikasikan, dan mensinergiskannya; sehingga menjadi keilmuan yang utuh-integral-integratif.
\end{abstract}

Kata Kunci: Integrated Twin Towers, Islamisasi Ilmu, dan Komparasi. 


\section{A. Pendahuluan}

Pada kisaran abad ke VI-XII M, dunia Islam mengalami supremasi kejayaan dan kemegahan dalam hal iptek dan peradaban, yang ditandai dengan maraknya kajian tentang ilmu pengetahuan dan filsafat, sehingga saat itu dunia Islam menjadi mercusuar dunia, baik di belahan Timur maupun Barat. Masa tersebut telah mampu memproduk banyak saintis dan filosof kaliber dunia di berbagai lapangan ilmu pengetahuan, misalnya, dalam bidang fikih: Imam Malik, Imam Syafi'i, Imam Abu Hanifah, Imam Ahmad bin Hanbal; dalam bidang filsafat: al-Kindi, al-Farabi, Ibnu Sina, dan Abu Yazid; dalam bidang sains: Ibnu Hayyam, al-Khawarizmi, al-Razi, dan al-Mas'udi. ${ }^{1}$

Keadaan seperti tersebut di atas dapat terealisasi karena ilmu pengetahuan, filsafat, dan agama diyakini sebagai suatu totalitas dan integralitas ajaran Islam yang tidak dipisahkan secara dikotomis antara satu dengan yang lain. Posisi ilmu pengetahuan dan siapapun yang mencarinya, secara religius, dipandang tinggi dan mulia. Mereka mengadakan eksplorasi dan invensi ilmu pengetahuan dan filsafat dengan tidak bertendensi pada persoalan materi semata, melainkan karena semangat religiusitas dan termotivasi oleh sebuah keyakinan bahwa aktivitas tersebut merupakan bagian integral dari manifestasi aplikasi agama (perintah Allah SWT). ${ }^{2}$

Pada sekitar pertengahan abad ke-12 M, kondisi gemilang di bidang keilmuan yang telah dicapai oleh dunia Islam, mulai bergeser dan sedikit demi sedikit menjauhi dunia Islam. Hal tersebut berawal dari terjadinya disintegrasi pemerintahan Islam yang berimplikasi pada munculnya sektesekte politik yang sparatif-kontradiktif. Sebagian sekte, secara politis, memproklamirkan akan ketertutupan pintu ijtihad dan menggiring umat Islam ke sudut pemaknaan agama yang eksklusif serta mengisolasikan ilmu pengetahuan dan filsafat dari dimensi agama. Hal ini berkonsekwensi pada terjadinya stagnasi sains di dunia Islam, serta berimplikasi pada kerapuhan dan kelumpuhan umat Islam dalam berbagai aspek kehidupan; baik militer, ekonomi, politik, maupun aspek keilmuan. ${ }^{3}$

\footnotetext{
${ }^{1}$ Harun Nasution, Pembaharuan dalam Islam (Jakarta: Bulan Bintang, 1975), 13.

${ }^{2}$ Muhammad Qutb, Qabasat min al-Rasul (Makkah: Dar al-Syarqi, 1982), 42-43.

${ }^{3}$ Harun Nasution, Pembaharuan dalam Islam, 13. 
Situasi dan kondisi yang kritis tersebut di atas dimanfaatkan oleh dunia Barat sebagai momentum jitu untuk menapakkan kaki kolonialisme dan imperialismenya terhadap dunia Islam. Wilayah-wilayah Islam satu persatu mereka taklukkan dengan mudah. Pada akhirnya suramlah dunia Islam dan reduplah pamornya di mata dunia sampai sekarang. Mengomentari hal itu, Isma'il Raji al-Faruqi ${ }^{4}$ menyatakan bahwa umat Islam di dunia ini merupakan umat yang kondisinya paling tidak menggembirakan, sekalipun dalam kuantitas besar dan berdomisili di dataran bumi yang subur dan kaya sumber daya alamnya.

Pada sekitar abad ke-18 M (periode modern) dan seterusnya (sampai sekarang), umat Islam tampaknya mulai terbangun dari tidur panjangnya. Jatuhnya Mesir ke tangan bangsa Barat menyadarkan dan membuka mata umat Islam bahwa di Barat telah muncul peradaban baru yang lebih tinggi dan sekaligus menjadi ancaman besar bagi umat Islam. ${ }^{5}$ Mulai saat itu muncul di kalangan intelektual Islam ide-ide untuk mempelajari ilmu pengetahuan Barat yang sekularistik dan rasional-materialistik serta terpisah sama sekali dari ruh dan nilai-nilai moralitas Islam.

Pertautan dunia Islam dengan ilmu pengetahuan Barat itu akhirnya menimbulkan persaingan dan dua macam respon yang saling bersimpangan jalan di kalangan intelektual Muslim. Satu sisi mereka menampakkan sikap antagonistik-kontradiktif, bahkan mereka menganggap ilmu pengetahuan Barat sebagai karya-karya jahat dan hanya sebagai gembar-gembor dunia yang hampa. Di sisi lain, terdapat kelompok intelektual Muslim yang menunjukkan sikap protagonis-kompromistis dan bombastis, bahkan terpaku dan terjerembab dalam metodologi sekular sains modern, misalnya: Muhammad Hisyam Haykal, Thaha Husain, dan Ali Abdul Raziq. Ketiga intelektual tersebut berpegang seutuhnya pada pandangan sains modern, bahkan mereka dengan terbuka mengekspresikan sentimen-sentimen anti agama. ${ }^{6}$

Kondisi tersebut tentu mempertajam kesenjangan antara ilmu pengetahuan dan agama dan memperkuat dikotomi keilmuan (agama dan

\footnotetext{
${ }^{4}$ Isma'il Raji al-Faruqi, Tauhid,, terj. Rahmani Astuti (Bandung: Pustaka, 1982), vii.

5 Isma'il Raji al-Faruqi, "Science and Traditional Values in Islamic Society", dalam Zygon, Journal of Religion and Science, Vol. 2, Nomor 3, 1967, 23.

${ }^{6}$ Osman Bakar, Tauhid dan Sains, terj. Yuliani Liputo (Bandung: Pustaka Hidayah, 1991), 220.
} 


\section{H. Syaifuddin}

umum; klasik dan modern; ukhrawi dan duniawi) yang pada gilirannya merambat pada dikotomi model pendidikan. Di satu pihak, ada pendidikan yang hanya memperdalam ilmu pengetahuan modern yang kering dari nilainilai moralitas agama (Islam); sementara di pihak lain, terdapat pendidikan yang hanya mendalami ilmu agama yang terpisahkan sama sekali dari perkembangan ilmu pengetahuan kontemporer.

Tipologi yang pertama hanya berorientasi untuk memproduk para saintis sekular yang sama sekali terlepas bahkan alergi terhadap prinsipprinsip dan nilai-nilai moralitas agama, sedangkan tipologi yang kedua hanya berorientasi untuk memproduk intelektual agama yang berwawasan eksklusif dan memisahkan bahkan melempar jauh-jauh ilmu pengetahuan umum (modern) dari paradigma pemahaman dan pemaknaan agama.

Ahmad Watik Pratiknya ${ }^{7}$ menyatakan bahwa munculnya kecenderungan dikotomi sesungguhnya berangkat dari kegagalan umat Islam untuk memahami dan menangkap hubungan antara ilmu dan agama secara proporsional. Sebenarnya menurut prinsip Islam, eksistensi manusia memiliki dua fungsi fundamental, yaitu sebagai hamba Allah dan sebagai pemimpin di muka bumi.

Pada posisinya sebagai hamba Allah, umat Islam dituntut untuk mengabdi kepada Allah dengan tunduk dan taat pada ketentuan-ketentuanNya. Sementara dalam posisinya sebagai khalifah di muka bumi, umat Islam dituntut untuk mau dan mampu mengatur, memelihara, dan mendayagunakan alam seisinya untuk kesejahteraan umat manusia. ${ }^{8}$ Demi mengaktualisasikan kedua fungsi tersebut, manusia harus memperbaiki hubungan dengan Tuhan yang berbentuk ibadah, dan juga harus memperbaiki hubungan dengan makhluk Tuhan dengan mengadakan penelitian pada hukum-hukum alam (sunnatullah) yang tergelar dalam sistemnya.

Dalam rangka upaya pengembalian totalitas dan integralitas pemahaman dan pemaknaan Islam ini, beberapa intelektual Muslim telah berusaha mencari solusi yang signifikan dan akurat dengan merekonstruksi

\footnotetext{
7 Ahmad Watik Pratiknya, "Identifikasi Masalah Pendidikan Agama Islam di Indonesia", dalam Muslih (Ed.), Pendidikan Islam di Indonesia (Yogyakarta: Tiara Wacana, 1991), 104.

${ }^{8}$ Hasan Langgulung, Manusia dan Pendidikan: Suatu Analisa Psikologi, Filsafat dan Pendidikan (Jakarta: Pustaka al-Husna, 1989), 32.
} 
paradigma pemikiran Islam yang populer disebut dengan "Islamisasi Ilmu Pengetahuan", yakni menerima secara positif sains modern dalam bingkai prinsip-prinsip dan nilai-nilai Islam. ${ }^{9}$ Di antara intelektual Muslim yang memprakarsai ide-ide Islamisasi ilmu pengetahuan adalah Isma'il Raji alFaruqi dan Naquib Al-Attas. Mereka memiliki persepsi bahwa ilmu pengetahuan modern dewasa ini telah bersifat sekuler dan karenanya jauh dari kerangka Tauhid. Karena itu, mereka menyerukan adanya renovasi dan rekonstruksi sistem pendidikan Islam yang mengarah pada kerangka Islamisasi ilmu. ${ }^{10}$

Islamisasi ilmu pengetahuan -sebagaimana yang dicanangkan AlFaruqi dan Al-Attas- merupakan bagian dari upaya intelektual Muslim untuk mengintegrasikan keilmuan dan memecahkan problem dikotomi pendidikan Islam. $^{11}$ Meski demikian, dalam merespon proyek Islamisasi ilmu pengetahuan tersebut, ada yang pro dan ada yang kontra di kalangan intelektual Muslim sendiri, termasuk di Indonesia. ${ }^{12}$ Di satu pihak, ada yang bersikap protagonis dan positif terhadap Islamisasi ilmu pengetahuan dengan berbagai argumen yang dikemukakan. Di pihak lain, ada yang bersikap antagonis dan negatif terhadap proyek Islamisasi ilmu pengetahuan dengan berbagai argumen yang ada.

Diantara intelektual Muslim yang termasuk dalam kategori kurang setuju dengan konsep integrasi keilmuan berbasis Islamisasi ilmu adalah intelektual struktural IAIN Sunan Ampel (Periode 2008-2012). Para intelektual struktural IAIN Sunan Ampel lebih setuju dengan upaya integrasi keilmuan berbasis integrated twin towers (menara kembar yang tersambug), dimana untuk mengkomunikasikan keilmuan agama dan umum, tidak perlu

\footnotetext{
${ }^{9}$ Osman Bakar, Tauhid dan Sains, 233.

10 John L. Esposito, "Isma'il Raji al-Faruqi”, dalam John L. Esposito (Ed.), The Oxfort Encyclopedia of The Modern Islamic World, Vol. 2 (New York: Oxford University Press, 1995), 3.

${ }^{11}$ Isma'il Raji al-Faruqi, Islamisasi Ilmu Pengetahuan, terj. A. Mahyudin (Bandung: Pustaka, 1984). Al-Faruqi memang sangat terobsesi untuk mengislamisasikan ilmu pengetahuan; lihat Azyumardi Azra, "Dari Arabisme ke Khilafatisme: Kasus Isma'il al-Faruqi”, dalam Azyumardi Azra, Pergolakan Politik Islam (Jakarta: Paramadina, 1996).

12 Ahmad Baidowi, "Islamisasi Ilmu Pengetahuan: Sebuah Respon terhadap Gagasan Isma'il Raji al-Faruqi", dalam Refleksi (Yogyakarta: IAIN SuKa Ushuludin, 2002).
} 


\section{H. Syaifuddin}

upaya Islamisasi ilmu; tetapi biarkan keilmuan agama dan umum berjalan sesuai dengan rel masing-masing, yang penting, pada puncaknya kedua keilmuan itu harus dikomunikasikan.

Paradigma keilmuan integrated twin towers bukanlah proses Islamisasi ilmu. Desain integrated twin towers berbeda dengan Islamisasi ilmu. Dalam paradigma integrated twin towers, tidak ada upaya untuk mengislamisasikan ilmu pengetahuan. Meskipun keduanya (antara integrated twin towers dan Islamisasi ilmu) merupakan gagasan yang berupaya untuk mengintegrasikan keilmuan agama dan umum dalam dunia pendidikan Islam, namun keduanya memiliki desain yang berbeda. Di sinilah menarik untuk mengkaji perbandingan di antara keduanya. Meski tujuannya sama, tetapi prosesnya berbeda. Hal ini perlu dikaji melalui penelitian. Sehingga tema penelitian ini menjadi penting dan signifikan.

\section{B. Desain Integrated Twin Towers}

Desain menara kembar tersambung (integrated twin towers) dalam keilmuan keislaman multidisipliner di UIN Sunan Ampel merupakan upaya membangun struktur keilmuan yang mana antara ilmu keagamaan dan ilmu sosial / humaniora serta ilmu alam berkembang secara memadai dan wajar. Kesemuanya memiliki kewibawaan yang sama, sehingga antara satu dengan lainnya tidak saling merasa superior atau inferior. Ilmu keislaman berkembang dalam kapasitas dan kemungkinan perkembangannya, demikian pula ilmu lainnya juga berkembang dalam rentang dan kapasitasnya. Ilmu keislaman ibarat sebuah menara yang satu dan ilmu lainnya seperti menara yang satunya lagi. Keduanya bertemu dalam puncak yang saling menyapa, yang dikenal dengan konsep ilmu keislaman multidisipliner.

Hubungan keilmuan agama dan umum tidak saling mengintervensi, tetapi saling melengkapi. Dengan demikian, tidak perlu upaya mengkaji secara khusus keilmuan umum dengan pendekatan agama untuk dicari relevansinya dengan ajara agama, tetapi cukup mengkomunikasikan diantara keduanya. Hal ini didasarkan pada kondisi keilmuan umum yang sudah mapan. Disamping itu, segala ilmu itu hakikatnya netral dan Islami. Baik buruknya ilmu tergantung pada penggunaannya. 
Desain integrated twin towers dapat dilihat pada gambar berikut: ${ }^{13}$

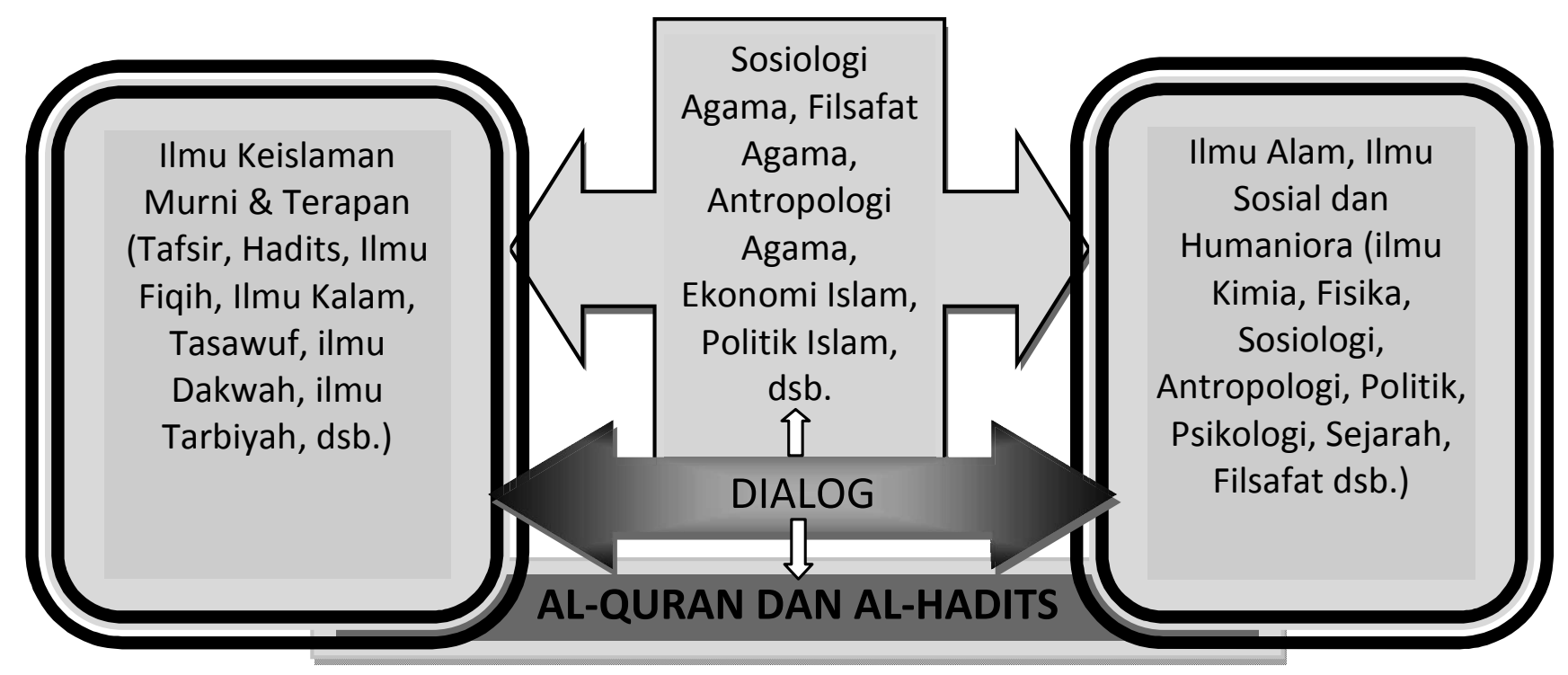

Gambar di atas menunjukkan bahwa fondasi keilmuannya adalah AlQuran dan Al-Hadits, kemudian menaranya terdiri dari ilmu keislaman murni dan terapan (Tafsir, Hadits, ilmu Fiqh, ilmu Kalam, Tasawuf, ilmu Dakwah, ilmu Tarbiyah, dan sebagainya), kemudian menara lainnya adalah ilmu alam, ilmu sosial dan humaniora (ilmu Kimia, Fisika, Sosiologi, Antropologi, Politik, Psikologi, Sejarah, Filsafat, dan sebagainya), dan kemudian dipuncaknya terdapat garis yang menghubungkan antara menara satu dengan lainnya, yaitu pertautan antara dua disiplin keilmuan (agama dan umum), sehingga terdapat sosiologi agama, filsafat agama, antropologi agama, ekonomi Islam, politik Islam, dan sebagainya.

Struktur bangunan keilmuan tersebut diatas harus diletakkan di atas fondasi Al-Quran dan Al-Hadits, sebab yang akan dibangun pada akhirnya adalah ilmu sosial profetik, ilmu alam profetik, serta culture dan humaniora profetik. Mengikuti pandangan kaum ilmuwan yang mengembangkan ilmuilmu yang bersifat trans-teoretik, yaitu teori yang tidak hanya digunakan untuk teori tetapi teori untuk kemungkinan pengembangan masyarakat.

13 Bandingkan dengan Moh. Faizin, Asumsi dan Resiko Pengembangan Epistemologi Twin Tower (Perspektif Filsafat Ilmu) (Surabaya: Lemlit IAIN SA, 2012). Lihat juga Muhammad Fahmi, "Pengembangan Epistemologi Twin Tower di IAIN Sunan Ampel: Antara Asumsi dan Resiko", Episteme, Vol. 7, No.1 (Tulungagung: PPs STAIN TA, 2012). 


\section{H. Syaifuddin}

Dengan demikian, setiap teori yang dihasilkan oleh ilmuwan Islam hakikatnya adalah bertujuan untuk meningkatkan kehidupan masyarakat setahap lebih baik.

Model integrated twin towers pun juga bukan model yang sangat sempurna. Kekuatan model ini adalah pada kemenyatuan pada puncaknya. Menara kembar yang kemudian dipersatukan melalui jembatan penyeberangan atau pendekatan sehingga menghasilkan keilmuan yang bercorak khas. Masing-masing menara memang merupakan bidang atau disiplin ilmu yang berbeda. Antara yang satu dengan lainnya berada di ruangnya sendiri-sendiri. Hal itu tentu disebabkan oleh masing-masing objek kajiannya yang berbeda. Objek ilmu alam tentu saja berbeda dengan ilmu sosial. Demikian pula humaniora dan ilmu budaya.

Dalam konteks bidang ilmu yang berdiri sendiri tentunya harus ditempatkan di dalam rumahnya sendiri-sendiri. Sehingga gambaran realitas empirisnya menjadi sangat kuat. Kemudian, di antara menara tersebut disambungkan dengan pendekatan atau bagan epistemologis yang saling mengaitkan dua bidang yang berbeda tersebut. Jembatan pendekatan akan menghasilkan bidang ilmu yang berciri khas. Inilah yang menjadi kekuatan dari integrated twin towers. Ia merupakan gabungan dari dua bidang ilmu yang memang berbeda, tetapi dipertemukan menjadi satu melalui pembuatan atau konstruksi epistemologis yang memang disengaja untuk itu.

Diantara model realitas yang belum memberikan gambaran secara menyatu adalah pada fondasi atau basis ontologis keilmuannya. Agar menjadi menyatu basis ontologisnya atau sumber keilmuannya, maka dua tower ini juga harus menyatu di pondasinya. Jadi, jika di bawah menyatu di dalam pondasinya, maka di atas menyatu melalui jembatan yang menghubungkan di antara dua tower dimaksud. Kemenyatuan antara bawah dan atas, antara pondasi dan puncak, antara aspek ontologis dan epistemologis, akan menghasilkan ilmu keislaman multidispliner. Ilmu inilah nantinya yang akan membedakan antara universitas Islam dengan universitas umum dalam melihat realitas empiris di masyarakat. Islamic studies multidisipliner merupakan puncak dari cita-cita mendirikan institusi pendidikan Islam yang ideal. ${ }^{14}$

\footnotetext{
${ }^{14}$ Nur Syam, Menegaskan lagi Integrative Twin Tower.
} 
Paradigma keilmuan integratif-interkonektif merupakan bangunan keilmuan universal yang tidak memisahkan secara dikotomis antara wilayah keilmuan agama dan keilmuan umum. Dalam bangunan keilmuan ini, ilmu pengetahuan agama (Islam) tidak lagi terpisah secara dikotomis dengan ilmu pengetahuan umum sebagaimana yang terjadi selama ini. Dalam format keilmuan yang terpadu, orientasi ilmu pengetahuan yang ingin ditekankan merupakan perpaduan antara ilmu-ilmu qauliyah / hadharah an-nash (ilmu yang bekaitan dengan teks keagamaan) dengan ilmu-ilmu kauniyah ijtima'iyah / hadharah al-'ilm (ilmu kealaman dan kemasyarakatan) dan ilmu hadaharah al-falsafah (ilmu etika kefilsafatan).

Ilmu-ilmu keislaman yang mengandung nilai normatif-formalistikdoktrinal disejajarkan dengan ilmu umum yang cenderung sosiologishistoris-empiris untuk menghasilkan suatu bangunan keilmuan baru. Melalui gabungan kedua perspektif ini, baik ilmu agama atau umum, tidak saling mensubordinasi tetapi berada dalam suatu kesatuan atau kesejajaran yang seimbang.

\section{Desain Islamisasi Ilmu}

Islamisasi ilmu merupakan suatu respon terhadap krisis masyarakat modern yang disebabkan karena pendidikan Barat yang bertumpu pada suatu pandangan dunia yang lebih bersifat materialistis-sekuleristik; yang menganggap bahwa pendidikan bukan untuk membuat manusia bijak, yakni mengenali dan mengakui posisi masing-masing dalam tertib realitas tapi memandang realitas sebagai sesuatu yang bermakna secara material bagi manusia, dan karena itu hubungan manusia dengan tertib realitas bersifat eksploitatif bukan harmonis. ${ }^{15}$ Ini adalah salah satu penyebab munculnya krisis masyarakat modern.

Islamisasi ilmu mencoba mencari akar-akar krisis tersebut. Akarakar krisis itu diantaranya dapat ditemukan dalam ilmu pengetahuan, yakni konsepsi atau asumsi tentang realitas yang dualistis, sekuleristik, evolusioneristis, dan karena itu pada dasarnya bersifat relativistis dan nihilistis. Islamisasi ilmu merupakan suatu upaya pembebasan pengetahuan

15 Aminullah Elhady, "Naquib Al-Attas: Islamisasi Ilmu", dalam Khudlori Sholeh (Editor), Pemikiran Islam Kontemporer (Yogyakarta: Jendela, 2003), 331-332. 


\section{H. Syaifuddin}

dari asumsi-asumsi atau penafsiran-penafsiran Barat terhadap realitas, kemudian menggantikannya dengan pandangan dunia Islam.

Selain itu Islamisasi ilmu juga muncul sebagai reaksi adanya konsep dikotomi antara agama dan ilmu pengetahuan umum yang dimasukkan masyarakat Barat dan menjadi budaya masyarakat modern. Masyarakat yang disebut terakhir ini misalnya memandang sifat, metode, setruktur sains dan agama jauh berbeda, meski tidak mau dikatakan kontradiktif. Sains meneropong sesuatu dari segi objektifnya. Agama melihat problematika dan solusinya melalui petunjuk Tuhan, sedangkan sains melalui eksperimen dan rasio manusia. Oleh karena ajaran agama diyakini sebagai petunjuk Tuhan, kebenaran dinilai mutlak, sedangkan kebenaran sains relatif. Agama banyak berbicara yang gaib sedangkan sains hanya berbicara mengenai hal yang empiris.

Dalam perspektif sejarah, sains dan teknologi modern yang telah menunjukkan keberhasilannya dewasa ini mulai berkembang di Eropa dalam rangka gerakan renaissance pada tiga atau empat abad yang silam. Gerakan ini berhasil menyingkirkan peran agama dan mendobrak dominasi gereja Roma dalam kehidupan sosial dan intelektual masyarakat Eropa sebagai akibat dari sikap gereja yang memusuhi ilmu pengetahuan. ${ }^{16}$ Dengan kata lain ilmu pengetahuan di Eropa dan Barat mengalami perkembangan setelah memisahkan diri dari pengaruh agama. Setelah itu berkembanglah pendapatpendapat yang merendahkan agama dan meninggikan sains.

Dalam perkembangannya, sains dan teknologi modern dipisahkan dari agama, karena kemajuannya yang begitu pesat di Eropa dan Amerika sebagaimana yang disaksikan sampai sekarang. Sains dan teknologi yang demikian itu selanjutnya digunakan untuk mengabdi kepada kepentingan manusia semata-mata, yaitu untuk tujuan memuaskan hawa nafsunya, menguras isi alam untuk tujuan memuaskan nafsu konsumtif dan materialistik, menjajah dan menindas bangsa-bangsa yang lemah, melanggengkan kekuasaan dan tujuan lainnya.

Penyimpangan dari tujuan penggunaan ilmu pengetahuan itulah yang direspon melalui konsep Islamisasi ilmu, yaitu upaya menempatkan sains

\footnotetext{
${ }^{16} \mathrm{http}: / /$ meetabied.wordpress.com/2009/11/01/kedudukan-filsafat-ilmu-dalamislamisasi-ilmu-pengetahuan-dan-kontribusinya-dalam-krisis-masyarakat-modern/, akses 14-05-2013

Jurnal Pendidikan Agama Islam Volume 01 Nomor 01 Mei 2013 Hal $10-20$
} 
dan teknolo gi dalam bingkai Islam, dengan tujuan agar perumusan dan pemanfaatan sains dan teknologi itu ditunjukkan untuk mempertinggi harkat dan martabat manusia, melaksanakan fungsi kekhalifahannya di muka bumi serta tujuan-tujuan luhur lainnya. Inilah yang menjadi salah satu misi Islamisasi ilmu.

Dalam penelusuran yang dilakukan oleh Ummi di UIN Malang, ditemukan beberapa versi pemahaman tentang Islamisasi ilmu pengetahuan. ${ }^{17}$ Pertama, Islamisasi ilmu pengetahuan merupakan sekedar memberikan ayat-ayat yang sesuai dengan ilmu pengetahuan umum yang ada (ayatisasi). Kedua, Islamisasi dilakukan dengan cara mengislamkan orangnya. Ketiga, Islamisasi yang berdasarkan filsafat Islam yang juga diterapkan di UIN Malang dengan mempelajari dasar metodologinya. Keempat, Islamisasi dipahami sebagai sebuah ilmu pengetahuan yang beretika atau beradab. Dengan berbagai pandangan dan pemaknaan yang muncul secara beragam ini perlu kiranya untuk diungkap dan agar lebih dipahami apa yang dimaksud "Islamisasi Ilmu Pengetahuan".

Menurut al-Faruqi, Islamisasi adalah usaha untuk mendefinisikan kembali, menyusun ulang data, memikirkan kembali argumen dan rasionalisasi yang berkaitan dengan data itu, menilai kembali kesimpulan dan tafsiran, memproyeksikan kembali tujuan-tujuan dan melakukan semua itu sedemikian rupa sehingga disiplin-disiplin ini memperkaya wawasan Islam dan bermanfaat bagi cita-cita. ${ }^{18}$

Dalam rangka menuangkan kembali keseluruhan khazanah pengetahuan umat manusia menurut wawasan Islam, bukanlah tugas yang ringan yang harus dihadapi oleh intelektual-intelektual dan pemimpinpemimpin Islam saat ini. Oleh karena itulah, untuk melandingkan gagasannya tentang Islamisasi ilmu, al-Faruqi meletakkan "prinsip tauhid" sebagai kerangka pemikiran, metodologi dan cara hidup Islam. Prinsip tauhid ini dikembangkan oleh al-Faruqi menjadi lima (5) macam kesatuan, yaitu: (1) Kesatuan Tuhan, (2) Kesatuan ciptaan, (3) Kesatuan kebenaran dan Pengetahuan, (4) Kesatuan kehidupan, dan (5) Kesatuan kemanusiaan. ${ }^{19}$

17 Ummi, Islamisasi Sains Perspektif UIN Malang, dalam Inovasi: Majalah Mahasiswa UIN Malang, Edisi 22. Th. 2005.

${ }^{18}$ Ismail Raji Al-Faruqi, Islamisasi Pengetahuan (Bandung: Pustaka, 1984).

${ }^{19}$ Ismail Raji Al-Faruqi, Islamisasi Pengetahuan. 


\section{H. Syaifuddin}

Secara umum, Islamisasi ilmu tersebut dimaksudkan untuk memberikan respon positif terhadap realitas ilmu pengetahuan modern yang sekuleristik dan Islam yang "terlalu" religius, dalam model pengetahuan baru yang utuh dan integral tanpa pemisahan di antaranya. Sebagai panduan untuk usaha tersebut, al-Faruqi menggariskan satu kerangka kerja dengan lima tujuan dalam rangka Islamisasi ilmu, tujuan yang dimaksud adalah: 1 . Penguasaan disiplin ilmu modern. 2. Penguasaan khazanah warisan Islam. 3. Membangun relevansi Islam dengan masing-masing disiplin ilmu modern. 4. Memadukan nilai-nilai dan khazanah warisan Islam secara kreatif dengan ilmu-ilmu modern. 5. Pengarahan aliran pemikiran Islam ke jalan-jalan yang mencapai pemenuhan pola rencana Allah SWT. ${ }^{20}$

Di samping itu, ada beberapa pengembangan definisi dari Islamisasi ilmu pengetahuan tersebut. Sebagaimana yang diungkapkan oleh Osman Bakar, Islamisasi ilmu pengetahuan adalah sebuah program yang berupaya memecahkan masalah-masalah yang timbul karena perjumpaan antara Islam dengan sains modern sebelumnya. ${ }^{21}$ Progam ini menekankan pada keselarasan antara Islam dan sains modern tentang sejauhmana sains dapat bermanfaat bagi umat Islam. M. Zainuddin menyimpulkan bahwa Islamisasi pengetahuan pada dasarnya adalah upaya pembebasan pengetahuan dari asumsi-asumsi Barat terhadap realitas dan kemudian menggantikannya dengan world view-nya sendiri (Islam). ${ }^{22}$

Menurut Wan Mohd Nor Wan Daud, proses Islamisasi ilmu pada dasarnya telah berlangsung sejak permulaan Islam hingga zaman sekarang ini. Ayat-ayat terawal yang diwahyukan kepada nabi secara jelas menegaskan semangat Islamisasi ilmu kontemporer, yaitu ketika Allah SWT menekankan bahwa Dia adalah sumber dan asal ilmu manusia. Ide yang disampaikan al-Quran tersebut membawa suatu perubahan radikal dari pemahaman umum bangsa Arab pra-Islam, yang menganggap suku dan

\footnotetext{
${ }^{20}$ Ismail Raji Al-Faruqi, Islamisasi Pengetahuan.

${ }^{21}$ Osman Bakar, Tauhid dan Sains (Bandung: Pustaka Hidayah, 1994)

${ }^{22}$ M. Zainuddin, Filsafat Ilmu: Perspektif Pemikiran Islam (Malang: Bayu Media, 2003).
} 
tradisi kesukuan serta pengalaman empiris, sebagai sumber ilmu pengetahuan dan kebijaksanaan. ${ }^{23}$

Pada sekitar abad ke-8 M, pada masa pemerintahan Daulah Bani Abbasiyah, proses Islamisasi ilmu ini berlanjut secara besar-besaran, yaitu dengan dilakukannya penerjemahan terhadap karya-karya dari Persia dan Yunani yang kemudian diberikan pemaknaan ulang disesuaikan dengan konsep agama Islam. Salah satu karya besar tentang usaha Islamisasi ilmu adalah hadirnya karya Imam al-Ghazali, Tahafut al-Falasifah, yang menonjolkan 20 ide yang asing dalam pandangan Islam yang diambil oleh pemikir Islam dari falsafah Yunani, beberapa di antara ide tersebut bertentangan dengan ajaran Islam yang kemudian dibahas oleh al-Ghazali disesuaikan dengan konsep aqidah Islam. Hal yang sedemikian itu, walaupun tidak menggunakan pelabelan Islamisasi, tapi aktivitas yang sudah dilakukan senafas dengan makna Islamisasi.

Di samping itu, pada tahun 1930-an, Muhammad Iqbal menegaskan akan perlunya melakukan proses Islamisasi terhadap ilmu pengetahuan. Beliau menyadari bahwa ilmu yang dikembangkankan oleh Barat telah bersifat ateistik, sehingga bisa menggoyahkan aqidah umat, sehingga beliau menyarankan umat Islam agar "mengonversikan ilmu pengetahuan modern". Akan tetapi, Iqbal tidak melakukan tindak lanjut atas ide yang dilontarkannya tersebut. Tidak ada identifikasi secara jelas problem epistimologis mendasar dari ilmu pengetahuan modern Barat yang sekuler itu, dan juga tidak mengemukakan saran-saran atau program konseptual atau metodologis untuk megonversikan ilmu pengetahuan tersebut menjadi ilmu pengetahuan yang sejalan dengan Islam.

Ide Islamisasi ilmu ini dimunculkan kembali oleh Sayyed Hossein Nasr, pemikir muslim Amerika kelahiran Iran, tahun 60-an. Beliau menyadari akan adanya bahaya sekulerisme dan modernisme yang mengancam dunia Islam, karena itulah beliau meletakkan asas untuk konsep sains Islam dalam aspek teori dan praktik melalui karyanya Science and Civilization in Islam (1968) dan Islamic Science (1976). Nasr mengklaim

${ }^{23}$ Wan Mohd Nor Wan Daud, The Educational Philosophy and Practice of Syed Muhammad Naquib al-Attas, diterjemahkan oleh Hamid Fahmy dkk, Filsafat dan Praktik Pendidikan Islam Syed M. Naquib al-Attas (Bandung: Mizan, 1998) 
bahwa ide-ide Islamisasi yang muncul kemudian merupakan kelanjutan dari ide yang pernah dilontarkannya. ${ }^{24}$

Gagasan tersebut kemudian dikembangkan oleh Naquib Al-Attas sebagai proyek "Islamisasi" yang mulai diperkenalkannya pada Konferensi dunia mengenai Pendidikan Islam yang Pertama di Makkah pada tahun 1977. Al-Attas dianggap sebagai orang yang pertama kali menegaskan perlunya Islamisasi pendidikan, Islamisasi sains, dan Islamisasi ilmu. Dalam pertemuan itu beliau menyampaikan makalah yang berjudul "Preliminary Thoughts on the Nature of Knowledge and the Definition and Aims of Education". Ide ini kemudian disempurnakan dalam bukunya Islam and Secularism (1978) dan The Concepts of Education in Islam A Framework for an Islamic Philosophy of Education (1980). Persidangan inilah yang kemudian dianggap sebagai pembangkit proses Islamisasi selanjutnya. ${ }^{25}$

Berdasarkan identifikasi Hanna Djumhana Bastaman, setelah cukup lama berkembang, Islamisasi melahirkan beberapa bentuk pola pemikiran, mulai dari bentuk yang paling superfisial sampai dengan bentuk yang agak mendasar. Bastaman mengistilahkannya sebagai; 1) Similarisasi, yaitu menyamakan begitu saja konsep-konsep yang berasal dari agama, padahal belum tentu sama; 2) Paralelisasi, yaitu menganggap paralel konsep yang berasal dari sains karena kemiripan konotasinya, tanpa mengidentikkan keduanya; 3) Komplementasi, yaitu antara sains dan agama saling mengisi dan saling memperkuat satu sama lain dengan tetap mempertahankan eksistensinya masing-masing; 4) Komparasi, yaitu membandingkan konsep / teori sains dengan konsep / wawasan agama mengenai gejala-gejala yang sama; 5) Induktifikasi, yaitu asumsi-asumsi dasar dari teori-teori ilmiah yang didukung oleh temuan-temuan empirik dilanjutkan pemikirannya secara teoritis-abstrak ke arah pemikiran metafisik, kemudian dihubungkan dengan prinsip-prinsip agama dan al-Quran mengenai hal tersebut; dan 6) Verifikasi, yaitu mengungkapkan hasil-hasil penelitian ilmiah yang menunjang dan membuktikan kebenaran ayat-ayat al-Quran. ${ }^{26}$

24 Miftahul Huda, Historisitas Islamisasi Ilmu Pengetahuan, dalam http://drmiftahulhudauin. multiply.com/journal/item/13,akses 14-05-2013

25 Miftahul Huda, Historisitas Islamisasi Ilmu Pengetahuan, dalam http://drmiftahulhudauin. multiply.com/journal/item/13,akses 14-05-2013

${ }^{26}$ Hanna Djumhana Bastaman, Integrasi Psikologi dengan Islam: Menuju Psikologi Islami (Yogyakarta: Pustaka Pelajar, 1997).

Jurnal Pendidikan Agama Islam

Volume 01 Nomor 01 Mei 2013

Hal $14-20$ 
Keenam pola pemikiran yang diidentifikasi Bastaman di atas, masih menampakkan jurang pemisah antara keduanya, agama yang pada dasarnya bersumber dari keimanan yang bersifat metafisik tidak begitu saja dapat dihubungkan dengan ilmu pengetahuan yang lebih bercorak empirik dan merupakan produk akal dan intelektual manusia. Meski demikian, pola-pola pemikiran tersebut harus tetap dihargai sebagai upaya untuk Islamisasi ilmu pengetahuan. $^{27}$

Dalam merealisasikan tujuan-tujuan Islamisasi ilmu, al-Faruqi menyusun 12 langkah yang harus ditempuh terlebih dahulu, yaitu: 1 . Penguasaan disiplin ilmu modern (prinsip, metodologi, masalah, tema dan perkembangannya), 2. Survei disiplin ilmu, 3. Penguasaan khazanah Islam (ontologi), 4. Penguasaan khazanah ilmiah Islam (analisis), 5. Penentuan relevansi Islam yang khas terhadap disiplin-disiplin ilmu, 6. Penilaian secara kritis terhadap disiplin keilmuan modern dan tingkat perkembangannya di masa kini, 7. Penilaian secara kritis terhadap khazanah Islam dan tingkat perkembangannya dewasa ini, 8. Survei permasalahan yang dihadapi umat Islam, 9. Survei permasalahan yang dihadapi manusia, 10. Analisis dan sintesis kreatif, 11. Penuangan kembali disiplin ilmu modern kedalam kerangka Islam, 12. Penyebarluasan ilmu yang sudah diislamkan. ${ }^{28}$

Dalam rangka mengaplikasikan Islamisasi ilmu, dapat dimulai dari level ilmu yang ada di perguruan tinggi. Level TK sampai SMA juga penting, tapi mereka sebenarnya bergantung pada guru-guru yang mengajar mereka. Guru yang mengajar TK sampai SMA, semuanya produk dari perguruan tinggi. Penulis-penulis buku pun kebanyakan dibuat oleh (lulusan) perguruan tinggi. Jadi, walaupun targetnya sekolah dasar, yang harus diubah pertama adalah guru-gurunya. Di Malaysia, proses Islamisasi mulai berlaku dalam hal tertentu, karena politik kerajaan di Malaysia memberikan perhatian khusus pada masalah pendidikan. Di Indonesia pun usaha-usaha untuk menerapkan pandangan Islam sudah ada.

\footnotetext{
27 Miftahul Huda, Historisitas Islamisasi Ilmu Pengetahuan, dalam http://drmiftahulhudauin. multiply.com/journal/item/13, akses 14-05-2013

${ }^{28}$ Ismail Raji Al-Faruqi, Islamisasi Pengetahuan.
} 


\section{Komparasi Integrated Twin Towers dan Islamisasi Ilmu}

Proses integrasi keilmuan agama dan umum melalui integrated twin towers dan Islamisasi ilmu memiliki persepsi yang berbeda. Oleh karena itu penting untuk membandingkan keduanya; mencari persamaan dan perbedaan di antara keduanya. Integrated twin towers membiarkan pengembangan keilmuan agama dan umum-sekuler secara wajar tanpa ada upaya intervensi diantara keduanya; yang penting keduanya dapat berdialog. Sementara Islamisasi ilmu berusaha memfilter keilmuan umum-sekuler dengan nilainilai Islam.

Integrated twin towers dimaksudkan untuk membangun struktur keilmuan yang mana antara ilmu keagamaan dan ilmu umum diposisikan berkembang secara wajar dan memadai. Kesemuanya memiliki kewibawaan yang sama, sehingga antara satu dengan lainnya tidak saling merasa superior atau inferior. Ilmu keislaman berkembang dalam kapasitasnya, dan ilmu umum juga berkembang dalam kapasitasnya. Ilmu keislaman laksana sebuah menara yang satu dan ilmu umum seperti menara yang satunya lagi. Keduanya bertemu dalam puncak yang saling menyapa, yang dikenal dengan konsep ilmu keislaman multidisipliner. Menara yang satu menjadi subject matter dan lainnya sebagai pendekatan.

Di antara desain yang sudah dirancang dalam rangka menjadikan ilmu-ilmu keislaman sebagai core dari seluruh keilmuan yang ada di UIN Sunan Ampel adalah akan ada program-program diversifikasi ilmu-ilmu kesilaman bagi seluruh SDM di perguruan tinggi ini. Program tersebut tidak dalam bentuk perkuliahan reguler, tetapi semacam pembelajaran intensif pada semester-semester awal. Nilai kelulusan pembelajaran intensif itu menjadi syarat untuk dapat mengikuti pembelajaran reguler pada semester perkuliahan.

Di dalam konsep pengembangan epistemologi integrated twin towers, keilmuan agama bukan bermaksud mengintervensi keilmuan umum, karena ilmu umum sudah mapan. Masing-masing ilmu berjalan bersamaan, dan ada saat pertemuan di antara keduanya. Wacana keislaman harus dikuasai, misalnya, untuk 1 (satu) tahun mereka diasramakan, terutama mahasiswa yang berasal dari background pendidikan umum. Selanjutnya ada model pendampingan ilmu-ilmu keislaman yang itu masuk dalam SKS. Jadi mahasiswa tidak dapat mengambil skripsi kalau tidak mengambil SKS ini, 
meskipun SKS ini tidak menjadi SKS murni. Jadi tidak ada dalam desain, sekularisasi ilmu keagamaan, yang ada justru rasionalisasi dan kontekstualisasi ilmu-ilmu keislaman.

Arah yang ingin dicapai dalam pengembangan epistemologi integrated twin towers adalah konsep ulul abab; yakni fikir, dzikir, amal sholeh. Fikir akan melahirkan kematangan inteleketual, dzikir akan mematangkan spiritual, amal sholeh akan melahirkan manusia yang berbudi luhur dan bermartabat. Semua ini yang akan dijual di IAIN Sunan Ampel; cerdas, luhur, bermartabat. IAIN Sunan Ampel akan berupaya matang dalam hal intelektual, spiritual, dan amal sholeh. Jadi tradisi-tradisi spiritual tetap harus dipertahankan di kampus Sunan Ampel. Shalat tetap shalat, tambah cerdas dan menjadi aktivis yang budiman.

Sementara itu Islamisasi ilmu merupakan usaha untuk mendefinisikan kembali, menyusun ulang data, memikirkan kembali argumen dan rasionalisasi yang berkaitan dengan data itu, menilai kembali kesimpulan dan tafsiran, memproyeksikan kembali tujuan-tujuan dan melakukan semua itu sedemikian rupa sehingga disiplin-disiplin ini memperkaya wawasan Islam dan bermanfaat bagi cita-cita. ${ }^{29}$

Islamisasi ilmu merupakan sebuah program yang berupaya memecahkan masalah-masalah yang timbul karena perjumpaan antara Islam dengan sains modern sebelumnya. ${ }^{30}$ Progam ini menekankan pada keselarasan antara Islam dan sains modern tentang sejauhmana sains dapat bermanfaat bagi umat Islam. Islamisasi ilmu pada dasarnya adalah upaya pembebasan pengetahuan dari asumsi-asumsi Barat terhadap realitas dan kemudian menggantikannya dengan world view-nya sendiri (Islam). ${ }^{31}$

Perbedaan antara integrasi keilmuan berbasis Islamisasi ilmu dengan integrated twin towers terletak pada prosesnya. Dalam prosesnya, desain Islamisasi ilmu berusaha mengintervensi kajian keilmuan umum dengan pendekatan kajian keagamaan; sedangkan dalam desain integrated twin towers keilmuan agama tidak bermaksud mengintervensi kajian keilmuan umum. Dalam integrated twin towers, keilmuan umum dibiarkan bejalan sesuai jalurnya tanpa ada intervensi, karena keilmuan tersebut sudah mapan;

${ }^{29}$ Ismail Raji Al-Faruqi, Islamisasi Pengetahuan (Bandung: Pustaka, 1984).

${ }^{30}$ Osman Bakar, Tauhid dan Sains (Bandung: Pustaka Hidayah, 1994)

${ }^{31}$ M. Zainuddin, Filsafat Ilmu: Perspektif Pemikiran Islam (Malang: Bayu Media, 2003). 


\section{H. Syaifuddin}

yang penting pada saat tertentu keilmuan umum tersebut perlu dikomunikasikan dengan keilmuan agama. Sementara dalam Islamisasi ilmu, keilmuan umum dianggap sekuler, sehingga perlu difilter dengan nilai-nilai Islam sebelum diadopsi oleh umat Islam.

Persamaan antara integrasi keilmuan berbasis Islamisasi ilmu dengan integrated twin towers terletak pada kurikulum dan tujuan. Dalam hal kurikulum, keilmuan yang dikaji dalam Islamisasi ilmu dan integrated twin towers adalah bidang kajian keilmuan agama dan umum. Sementara dalam hal tujuan, Islamisasi ilmu dan integrated twin towers sama-sama bertujuan untuk mengintegrasikan keilmuan agama dan umum, mendialogkannya, mengkomunikasikannya, dan mensinergiskannya; sehingga menjadi keilmuan yang utuh-integral-integratif. Hal ini didasarkan pada sebuah asumsi, bahwa hakikat ilmu adalah satu, bersumber dari Allah SWT, dan digunakan untuk memahami ayat-ayat Allah SWT, baik yang berupa ayatayat qauliyah (al-Quran) maupun ayat-ayat yang berupa kauniyah (hamparan alam semesta).

\section{E. Kesimpulan}

Pertama, desain integrated twin towers dilakukan dalam rangka menyongsong perubahan IAIN menjadi UIN Sunan Ampel. Dalam desain integrated twin towers posisi keilmuan agama dan umum tidak dicampur menjadi satu, tetapi dibiarkan berjalan sendiri-sendiri, dan pada saat tertentu dipertemukan untuk saling berdialog. Dalam desain integrated twin towers keilmuan agama tidak bermaksud mengintervensi keilmuan umum, karena keilmuan umum dianggap sudah mapan, jadi biarkan berjalan secara wajar pada posisinya; yang penting di antara kedua keilmuan itu bisa saling berkomunikasi.

Kedua, desain Islamisasi ilmu dilakukan dalam rangka mengkritisi keilmuan umum yang notabene banyak bersumber dari Barat dan bersifat sekuleristik, materialistik, dan individualistik. Dalam proses Islamisasi ilmu, keilmuan Islam berupaya mengintervensi keilmuan umum dalam rangka memfilterisasinya sehingga keilmuan tersebut menjadi Islami. Jadi Islamisasi ilmu berarti memberikan wawasan (world view) keislaman kedalam keilmuan umum. 
Ketiga, meskipun ada perbedaan di antara desain integrasi keimuan berbasis Islamisasi ilmu dengan integrated twin twoers, namun juga ada persamaannya. Perbedaannya terletak pada proses (epistemologi)-nya. Dalam prosesnya, desain Islamisasi ilmu berusaha mengintervensi kajian keilmuan umum dengan pendekatan kajian keagamaan; sedangkan dalam desain integrated twin towers keilmuan agama tidak bermaksud mengintervensi kajian keilmuan umum. Persamaannya terletak pada kurikulum (ontologi) dan tujuan (aksiologi). Dalam hal kurikulum, keilmuan yang dikaji dalam Islamisasi ilmu dan integrated twin towers adalah bidang kajian keilmuan agama dan umum. Sementara dalam hal tujuan, Islamisasi ilmu dan integrated twin towers sama-sama bertujuan untuk mengintegrasikan keilmuan agama dan umum, mendialogkan, mengkomunikasikan, dan mensinergiskannya; sehingga menjadi keilmuan yang utuh-integral-integratif.

\section{DAFTAR PUSTAKA}

Azyumardi Azra, "Dari Arabisme ke Khilafatisme: Kasus Isma'il al-Faruqi", dalam Azyumardi Azra, Pergolakan Politik Islam (Jakarta: Paramadina, 1996).

Ahmad Baidowi, "Islamisasi Ilmu Pengetahuan: Sebuah Respon terhadap Gagasan Isma'il Raji al-Faruqi", dalam Refleksi (Yogyakarta: IAIN SuKa Ushuludin, 2002).

Ahmad Watik Pratiknya, "Identifikasi Masalah Pendidikan Agama Islam di Indonesia", dalam Muslih (Ed.), Pendidikan Islam di Indonesia (Yogyakarta: Tiara Wacana, 1991).

Aminullah Elhady, "Naquib Al-Attas: Islamisasi Ilmu", dalam Khudlori Sholeh (Editor), Pemikiran Islam Kontemporer (Yogyakarta: Jendela, 2003).

Harun Nasution, Pembaharuan dalam Islam (Jakarta: Bulan Bintang, 1975).

Hasan Langgulung, Manusia dan Pendidikan: Suatu Analisa Psikologi, Filsafat dan Pendidikan (Jakarta: Pustaka al-Husna, 1989).

Hanna Djumhana Bastaman, Integrasi Psikologi dengan Islam: Menuju Psikologi Islami (Yogyakarta: Pustaka Pelajar, 1997). 
http://meetabied.wordpress.com/2009/11/01/kedudukan-filsafat-ilmu-dalamislamisasi-ilmu-pengetahuan-dan-kontribusinya-dalam-krisismasyarakat-modern/, akses 14-05-2013

Isma'il Raji al-Faruqi, Islamisasi Ilmu Pengetahuan, terj. A. Mahyudin (Bandung: Pustaka, 1984).

Isma'il Raji al-Faruqi, Tauhid,, terj. Rahmani Astuti (Bandung: Pustaka, 1982).

Isma'il Raji al-Faruqi, "Science and Traditional Values in Islamic Society", dalam Zygon, Journal of Religion and Science, Vol. 2, Nomor 3, 1967.

John L. Esposito, “Isma'il Raji al-Faruqi”, dalam John L. Esposito (Ed.), The Oxfort Encyclopedia of The Modern Islamic World, Vol. 2 (New York: Oxford University Press, 1995).

Muhammad Qutb, Qabasat min al-Rasul (Makkah: Dar al-Syarqi, 1982).

Moh. Faizin, Asumsi dan Resiko Pengembangan Epistemologi Twin Tower (Perspektif Filsafat Ilmu) (Surabaya: Lemlit IAIN SA, 2012).

Muhammad Fahmi, "Pengembangan Epistemologi Twin Tower di IAIN Sunan Ampel: Antara Asumsi dan Resiko", Episteme, Vol. 7, No.1 (Tulungagung: PPs STAIN TA, 2012).

M. Zainuddin, Filsafat Ilmu: Perspektif Pemikiran Islam (Malang: Bayu Media, 2003).

M. Zainuddin, Filsafat Ilmu: Perspektif Pemikiran Islam (Malang: Bayu Media, 2003).

Miftahul Huda, Historisitas Islamisasi Ilmu Pengetahuan, dalam http:// drmiftahulhudauin. multiply.com/journal/item/13, akses 14-05-2013

Nur Syam, Menegaskan lagi Integrative Twin Tower.

Nasution, Metodologi Penelitian Naturalistik Kualitatif (Bandung: Transtinto, 1996).

Osman Bakar, Tauhid dan Sains, terj. Yuliani Liputo (Bandung: Pustaka Hidayah, 1991).

Ummi, Islamisasi Sains Perspektif UIN Malang, dalam Inovasi: Majalah Mahasiswa UIN Malang, Edisi 22. Th. 2005.

Wan Mohd Nor Wan Daud, The Educational Philosophy and Practice of Syed Muhammad Naquib al-Attas, diterjemahkan oleh Hamid Fahmy dkk, Filsafat dan Praktik Pendidikan Islam Syed M. Naquib al-Attas (Bandung: Mizan, 1998). 